\title{
What conditions education for forgiveness in terms of the neo-Thomistic philosophy of education
}

\author{
Jarosław Horowski ${ }^{1}$ iD
}

Published online: 24 May 2018

(C) The Author(s) 2018

\begin{abstract}
The article addresses questions about the conditions of education for forgiveness, analysing them in terms of philosophy of education. The first part provides a review of the philosophical discussion on forgiveness. Revolving around the essence and moral value of forgiving, it is a debate which offers no explanations as to why people decide to forgive. In the light of this problem, the second part of the article seeks to view forgiveness as a moral decision. Neo-Thomistic philosophy is applied in the analysis, in which forgiveness appears to result from a dialogue between reason and will. The third part focuses on readiness to forgive which, in the Thomistic pedagogy, relates to the development of moral virtues; in particular, the cardinal virtues, i.e., prudence, justice, temperance and fortitude. The last part lists several conclusions applicable to pedagogy. They refer to the need for development of both intellect and will as a power sensitive to good.
\end{abstract}

Keywords Forgiveness · Neo-Thomistic pedagogy · Cardinal virtues · Education for forgiveness · Prudent forgiveness

\section{Introduction}

The analysis presented in this article aims to determine what factors condition forgiveness and education for forgiveness, in terms of the neo-Thomistic ${ }^{1}$ philosophy of education.

\footnotetext{
1 For the purposes of this article, i.e., the analysis of forgiveness and people's readiness to forgive, it is not necessary to make a distinction between the Thomistic and neo-Thomistic approach. However, it is offered in the article to provide more background for the literature used as a reference point throughout the analysis. In my research I do not refer as much to the writings of Thomas Aquinas as to the research of neo-Thomistic writers from the 20th century.
}

Jarosław Horowski

jarohor@umk.pl

1 Chair of Theory of Education, Faculty of Education Sciences, Nicolaus Copernicus University,

Toruń, Poland 
The importance of finding answers to these questions is related to the meaning of forgiveness itself. Decisions that we take every day are usually not made in neutral circumstances. We have to take them both with respect to those who are kind to us and those who have harmed us. In some cases it is necessary to resolve the dilemma whether to end a relationship with someone close to us who has done us wrong, or whether to forgive them and focus on building a common future with them. Every person is bound to err in their relations with other people and behave even very selfishly at times. Therefore, forgiveness becomes a condition for maintaining and strengthening human relations (Szulakiewicz 2016).

Although forgiveness, and consequently the ability to forgive, is a condition for human relations, it cannot be approached uncritically. An act of forgiveness may be associated with many risks which are often overlooked (Griswold 2014, pp. 6-7). If forgiven too hastily, the wrongdoer may not even notice that they have done something wrong, while the victim may be left without compensation for what they have lost. Such form of forgiveness denies justice. In extreme cases, when the wrongdoer bears no responsibility, the wronged person may be subject to secondary victimisation.

Due to its significance for human relations and risks connected with it, forgiveness becomes an important part of education. Under its framework it is possible to prepare people for forgiving as well as to establish its limits, so that forgiveness does not deny justice or lead to another act of wrong-doing. A particular risk arises when forgiveness is offered by the victim under emotion. Therefore, it is one of the tasks of education to prepare people for making a rational judgment and decide what may bring more good in a given situation.

In order to determine how forgiveness can be included in educational processes, it is necessary to look at it from the perspective of the philosophy of education. Such approach enables an analysis of two issues in this respect. Firstly, it can help us recognise and appreciate the value of forgiveness. A thorough philosophical analysis may for example improve our understanding of benefits and risks related to forgiveness, relationship between forgiveness and justice, as well as what rational forgiveness actually is. This is how philosophy of education can help place forgiveness among other aims and objectives of education (task no 1). Secondly, philosophy of education can also determine how, under certain social, cultural and educational circumstances, an individual can mature towards making a rational choice about forgiving (task no 2). Thus, by tapping into a variety of scientific research, including such sciences as psychology and sociology, philosophy of education can provide the theoretical grounds for specific educational activities.

The analysis presented in this article does not address the value of forgiveness for human development and interpersonal relations, or its value for the process of education: these issues would require a separate study. The purpose of this article is to define what determines forgiveness, and consequently, what determinants should be taken into account in order to support education for forgiveness. Therefore, the analysis offered below refers to the second of the aforementioned tasks faced by philosophy of education.

For the purposes of the analysis, a specific theoretical perspective has been adopted, namely that of the neo-Thomistic philosophy of education. It has been chosen for two reasons. Firstly, to date, this perspective has not been used to explore either forgiveness or education for forgiveness, despite its specific approach to education process and its general potential for interpretation. Secondly, it offers a new viewpoint on the reality of forgiveness and education for forgiveness, presenting it in a different light and in new dimensions. 
The attempt to approach this problem from the point of view of neo-Thomism was preceded by a thorough research into the literature on forgiveness. ${ }^{2}$ It revealed that in philosophical discussion, forgiveness tends to be perceived as a separate phenomenon, whereby less attention is paid to what conditions it. At the same time, it is actually these conditioning factors that are crucial from the pedagogical perspective. On the other hand, psychological studies seek to describe forgiveness as a process in time, reporting on personality conditions necessary for it to occur and the effects of forgiveness (Zarzycka 2016). However, such studies fail to answer one of the most important questions regarding education: what conditions forgiveness in terms of one's reason and will?

The analysis presented here starts with references to philosophical and psychological studies which provide the background necessary to appreciate the value of neo-Thomistic interpretation. The first section describes the specificity of philosophical reflections on forgiveness, following the example of a discussion inspired by the early-18th-century writings of the Anglican bishop Joseph Butler. In his sermons the bishop delved into the problem of forgiveness, referring both to the moral value of forgiveness and its importance for the individual's mental well-being. The choice of this discussion was dictated by the fact that it continued across a variety of scientific journals and was therefore recorded in a number of reliable sources. While primarily offering a valuable input regarding the essence of forgiveness, this debate does not refer to what actually conditions it. It may therefore be conducive to solving the first of the problems addressed by philosophy of education in terms of forgiveness (task no 1); however, it seems to be of less use when it comes to clarifying the other issue which I intend to analyse by applying the neo-Thomistic approach. The discussion is briefly outlined below to show its specific character and lesser value for explaining how to support people in their development towards rational forgiving as part of their educational process (task no 2).

In the second section I try to depict forgiveness as a moral decision, with particular emphasis on treating it as a 'decision'. Although forgiveness was perceived as a one-off act throughout the discussion summarised in the first section of the article, addressing it as a decision requires it to be presented as a process that occurs in time, depends on certain conditions, and has its own dynamics. Such an approach to forgiveness is possible in the neo-Thomistic philosophy; it is additionally supported by the results of psychological studies, which are also quoted in this section of the article.

The third section provides an introduction to neo-Thomistic pedagogy, which explores the possibility of improving decision-making acts. If forgiveness can be understood as a moral decision, then its conditions should be equivalent to those that influence an act of decision-making. Consequently, before forgiveness is implemented within the teleology of education, it is necessary to specify how education could support decision-making acts. Working towards the improvement of such acts, neo-Thomism suggests focusing on the development of moral virtues, particularly cardinal virtues. Therefore, the third section presents the link between one's readiness to forgive and one's embracement of moral virtues.

The final section offers some conclusions that can be drawn with respect to pedagogical practice. It must be underlined that the analysis presented in the article does not seek to

2 The analysis focuses mainly on the teachings of philosophers who disputed the approach to forgiveness proposed by Joseph Butler, published in the following journals: Ethics, Journal of Philosophy of Education, Journal of the History of Ideas, Midwest Studies in Philosophy, Ethics \& Education. These are discussed in the first section of the article. In terms of psychological research, significant works include those by Robert Enright, his colleagues and students. References to some of them may be found in the second section of the article. 
define at length the essence of forgiveness, especially given that the very term 'forgiveness' refers to a variety of processes which might be driven by different factors, but are similar in terms of effect. Essentially, this study focuses on identifying possible conditions that influence forgiveness and, as a result, defining the foundations for further pedagogical reflections on forgiveness. It indicates that the conditions in question should be looked for at the levels of reason, will and emotions. However, conditions are obviously not determinants. Forgiveness remains an individual act that cannot be triggered by educational activities, even if they are planned as carefully as possible. Thus, the conclusions formulated here can only be understood as suggestions that might facilitate creating circumstances conducive to one's decision to forgive.

\section{What stands behind forgiveness?}

Although integrally linked to human relations, the reality of forgiveness is not an easy one to define. This is evidenced for example by the philosophical discussion that unfurled across scientific journals with respect to the approach to forgiveness proposed in the early18th century by Bishop Joseph Butler in his Fifteen Sermons Preached at the Rolls Chapel (1827). In the text, he attempts to resolve the dilemma as to how far a human being should go in their pursuit for good, which they were called for upon creation, if they keep experiencing acts of evil from those around them. In Sermon VIII, Butler talks about resentment, only to move on to the topic of forgiveness in Sermon IX. When he ponders on resentment in Sermon VIII, he points to it as a natural "weapon put into our hands by nature, against injury, injustice and cruelty". He also observes that in many situations resentment no longer fulfils its defensive function and instead becomes the fundament for the attitude of revenge, so perpetuating moral faults in man. Sermon IX asks the question of how to prevent the natural reaction to injury from turning into the moral vice of vindictiveness. It is namely these vices that are evil. They make it impossible to do good, i.e., to do what the human being was summoned to do according to the Bible, they destroy interpersonal relations and allow evil to spread in the community. In this context, forgiveness appears to be a means of avoiding the danger of succumbing to the vice of vindictiveness.

Even though Joseph Butler is rather thorough in his analysis of resentment and forgiveness, none of his sermons offers a definition of forgiveness. Jeffrey G. Murphy takes up this challenge. His text based on Butler's writings concludes that the essence of forgiveness is to renounce resentment. He defines the forgiving person as the "one who has, on moral or religious grounds, forsworn resentment-forsworn the very personal response of anger or sometimes even hatred that one naturally (and perhaps properly) initially feels when one believes that one has been wronged by another" (Murphy 1982). It is an interesting approach, as rather than referring to a single act it characterises forgiveness as an attitude that arises from several specific motives (such as compassion or God's love) and a character disposition (Murphy 1998, p. 698). Therefore, Murphy identifies forgiveness with a virtue. He also points out that the essence of forgiveness is to renounce certain feelings towards the injuring party; these include resentment, anger and hatred.

As Murphy suggests, the interpretation of Butler's writings is primarily criticised for the range of feelings which are to be overcome in the process of forgiveness. For example, Norvin Richards observes that such definition of forgiveness does not cover the whole spectrum of feelings which may arise in response to being wronged. According to 
Richards, injury can also evoke contempt, sadness and disappointment, the elimination of which should also be recognised as forgiveness (Richards 1988, pp. 77-78). Inspired by his reflections he therefore proposes the following definition: "To forgive someone for something is to abandon all the hard feelings one bases on this particular episode. Were this positive effort not made, the feelings would continue" (pp. 80-81). Murphy acknowledges these arguments in one of his later works, admitting that forgiveness can also refer to hatred, loathing, contempt, indifference, disappointment or even sadness (Murphy 2003, p. 59).

Paul A. Newberry also does not agree with Murphy's interpretation of Butler's words and he claims that Butler "did not define forgiveness as the overcoming of resentment but rather as the checking of revenge, or forbearance" (Newberry 2001, p. 233). He moves on to point out that this error comes from the fact that modern interpretations of Butler's writings adopt a completely different theory of emotion (i.e., the cognitive theory of emotion) from that used by the Anglican Bishop which was the "feeling" theory of emotion. Analysing Butler's writings, Newberry emphasises that resentment understood as a direct emotion to injury is justified because it protects the injured party from being harmed once again ( $\mathrm{p}$. 235). As a consequence, he states that Butler only warns against the excess and abuse of this natural feeling (p. 236). This raises the question of what is abuse. Newberry says that abuse occurs when grief stands in the way of love for another person (p. 238).

Ernesto V. Garcia, like Newberry, argues that "forgiveness for Butler does not require that we entirely forswear resentment at all" (Garcia 2011, p. 2). On his reading of Butler's sermons, he concludes that the bishop distinguishes between two types of resentment: a non-moral one which is a direct reaction to pain and suffering, and a deliberate one which, as a response to injury, is addressed at the wrongdoer and may thus be subject to moral judgment. However, this judgment cannot be unequivocal. Garcia points out that resentment as such is a gift from our creator, valuable from the personal and social point of view, deserving condemnation only in its distorted form, i.e., when it means succumbing to the vices of malice and revenge (pp. 2-3). According to Garcia, forgiveness would therefore include "forswearing the vices of malice and revenge" and being "virtuously resentful" by not falling into the extremes of leniency and not caring for one's own good, or revenge and retaliation (p. 4). Nevertheless, Garcia does not completely agree with Newberry. He argues that one cannot separate their attitude from their feelings; thus forgiveness will always entail a change of one's feelings towards their wrongdoer (p. 6).

The philosophical discussion of forgiveness also revolves around its moral value. Some of its aspects may already be noticeable in the passages quoted above. Until which moment resentment is justified essentially remains a question of ethics. It is also through ethical aspects that, for example, the relation between forgiveness and justice is analysed. As referred to before, Murphy says that elimination of grief does not mean giving up justice, i.e., seeking punishment for the wrongdoer. The forgiving person cannot simply show leniency, remain indifferent to or be complicit in wrongdoing by not objecting clearly to injury (Murphy 1998, p. 698). Analysing the moral value of forgiveness from the perspective of the subject (forgiving person), Richards states that forgiveness is bad if it reinforces faults in the character of the forgiving person, such as cowardice or arrogance. The act of forgiveness is good when it allows for a manifestation of admirable qualities (Richards 1988, p. 80). Ethical discussion may therefore inspire conclusions as to when forgiveness is good or bad, in which circumstances one is obliged to forgive and in which it is just a supererogatory act.

The discussion of the essence of forgiveness is extremely interesting and it refers to a variety of issues unaddressed here. However, at this stage of the analysis there is no need to 
present it any further. Regarding the various interpretations of the essence of forgiveness and analysis of its moral value, it suffices to say that from the perspective of moral education it is necessary to analyse completely distinct aspects of this act. From the educational point of view, it is crucial to establish first how an act of forgiveness is born and in what conditions it is deliberate and positive, both for the individual and for other people. The afore-mentioned philosophical studies offer no solution to these problems. Let us therefore try to look at forgiveness as an act of decision taken by the injured party.

\section{Forgiveness as a moral decision}

The approaches to forgiveness discussed above all point to a link between forgiveness and a change of feelings. This aspect of the act or process of forgiveness is considered fundamental and, as such, it is widely discussed in terms of the essence of forgiveness. In my opinion, to determine the essence of the act of forgiveness it is necessary to consider another aspect, not so much related to feelings as to mental powers.

In his discussion of forgiveness, Murphy uses the term "forswearing" which is also applied by other authors. This means that mental powers are pivotal in the act of forgiveness, as they allow negative feelings to be overcome towards the wrongdoer. In the definitions of forgiveness this aspect is unfortunately treated as secondary, as if forgiveness "occurred" on its own instead of being brought about by a deliberate decision. When in 2006 the American Psychological Association began to publish its Research Briefs series to provide an overview of the most important topics relevant to the United Nations mission, priorities and agenda, one of its first brochures was devoted to forgiveness. It proposes to define forgiveness as a process which occurs in a person, without specifying whether this process is somehow influenced by them or remains independent of them. An additional assertion is made only in the second sentence that according to most scholars the source of forgiveness lies in a deliberate decision: "Forgiveness is a process (or the result of a process) that involves a change in emotion and attitude regarding an offender. Most scholars view this as an intentional and voluntary process, driven by a deliberate decision to forgive" (APA 2008, p. 5).

The dilemmas present in answering the question about the sources of the act of forgiveness also ensue from the ongoing debate on moral education that takes place among psychologists. When addressing the topic of forgiveness as character education for children and adolescents, Wei Neng Lin, Robert Enright and John Klatt first recount the discussion of character development. In their opinion, two opinions seem to be prevailing. According to the first, associated with the philosophical ideas of Aristotle and the behaviourist paradigm in psychology, moral life is made up of habitual behaviour. While moral development relates to individual's conformity to rules or norms and the conditioning of behaviours with appropriate reinforcement. In the light of this, character development entails instilling community values by promoting the student's emotional attachment to society and teaching them respect for society's rules and authority (Lin et al. 2011, p. 239).

The second view arises out of Piaget's cognitive theory and assumes that the essence of moral life is reflective thought about fairness and justice. For supporters of this approach, the most important part of character education is to construct the student's personal understanding of morality (Lin et al. 2011, p. 239). In between these two extremes, several intermediate views may be found which combine moral education, on the one hand, with the influence of the community, and on the other hand, with the help in acquiring 
individual moral awareness. In terms of the two views discussed above, the source of the attitude of forgiveness should therefore be sought either in social values instilled on the individual or in the individual's autonomous moral judgement.

However, both approaches are highly polarised and are a result of multiple reductionisms. While the former view places forgiveness in the sphere of social relations, it depreciates the character of its moral decision. The latter view may emphasise the role of the subject in taking the decision to forgive, but at the same time it suspends this decision in vacuum by not linking it to any motives arising from interpersonal relations. To understand the reductionism behind it, it is worth seeing how moral decision is conceptualised in Thomistic philosophy. Let us use this philosophical theory as a point of reference for a critical assessment of other approaches.

Addressing the topic of morality in his Summa Theologiae, Thomas Aquinas (1947) first offers an analysis of human act. He argues that the human being always acts for an end (aim) and by reaching it expects to achieve happiness (ST I-II, q. 1, a. 1). In the following articles, he moves on to explain what it means in practice. His analysis reveals that the human being is moved to act not by ideas, but by being which appears as a source of happiness (ST I-II, qq. 9-10). Applying this statement to the question about the origins of the act of forgiveness leads to several specific conclusions. It means that if forgiveness is a moral decision, its source lies in the good that the subject expects to achieve through forgiving. It is therefore wrong to conclude that one may be forced to forgive through exercising social pressure on them or "drilling an attitude of forgiveness" into them, just as it is wrong to conclude that a deliberate reflection on forgiveness may lead directly to the act of forgiveness.

Based on the philosophical analyses of Thomas Aquinas, a model of a decision-making act can be drawn. In this model, the decision arises in a dialogue between reason and will. This is one of the fundamental patterns in Thomistic philosophy (Gilson 1971). There is no need to present it here in its entirety; for the purposes of our discussion it is enough to refer to the stage of intending (ST I-II, qq. 12-15). At the stage of intending, the idea of good which arises in reason is confronted with the response from will in the form of the intention (intentio) or lack of the intention to achieve this good. Upon the appearance of the intention, reason considers the means necessary to this end (consilium), while the will allows some of them and rejects others (consensus). Of those approved by will, reason points to the best ones (judgement-iudicium) and the will chooses one of them (electio) (Mróz 2001, pp. 245-246).

It is important to emphasise that moral reasoning which, since Aristotle's times, has been referred to as practical reasoning or phronesis, is of specific nature, as every judgment made by reason is influenced by the will stimulated by the good for which it strives (Pieper 1966). In other words, the decision taken by a person seeking happiness in sensuous goods of pleasure will be different from those of a person who first cares about a relation with another person or whom, for the sake of peace and quiet, will ultimately prefer a conformist approach to life (Maritain 1990).

This model of the process of moral decision can easily be adapted to the act of forgiveness. It is determined not only by rational premises, which obviously are important, but by the end manifested in action, albeit not always consciously. For example, when someone wants to reconcile with the offender who once was very close to them. Or when someone wants to overcome negative emotions which appeared after they were wronged and which now prevent them from reaching inner harmony. It may also be exemplified by yielding to the pressure of a group close to the injured party whom they force to forgive. 
When bound to the end of the individual's actions, the moral value of forgiveness may be dubious. Forgiveness may then be given to a person who neither repents nor tries to correct their mistake, or does not even see the wrong they have caused, just because they are close to the person who they have wronged. Conversely, someone who shows repentance and seeks to make reparations for the harm they have done may not be forgiven because the injured party does not care to rebuild their relationship with them. The injured party's motives may also be of doubtful value. They can decide to forgive out of sheer laziness or conformism, or even because they have a different agenda in which forgiveness merely serves as a tool.

Based on the analysis presented so far, certain conclusions may be drawn as to what determines forgiveness. On the one hand, it will be conditioned by the understanding of the situation in which one is to take a decision whether to forgive or not to forgive. On the other hand it will be affected by the circumstances related to the well-being of the persons important to the forgiving party. Psychological research seems to confirm this relation partially. Studies show that the act of forgiveness is conditioned by moral reasoning, but it is also said to be dependent for example on the relationship with the wrongdoer or concern for one's own well-being.

The link between the decision to forgive and the level of moral reasoning has been shown for example in studies aimed at understanding forgiveness in those who forgive (Klatt and Enright 2009), or in studies devoted to the importance of cognitive attributions for the decision to forgive (Hall and Fincham 2006). However, it needs to be pointed out that the extent to which the forgiving party understands what forgiveness is and what effects it might bring does not tell us anything about their thinking at the very moment of taking the decision to forgive. The studies only confirm that the forgiving party understands the decision they make or that their level of intellectual development is typically higher. They do not reveal what their thought process specifically looks like and whether their decision was prudent or imprudent, whether it took into account the well-being of those directly or indirectly injured, what was the specific motive behind forgiveness, or what good was to be achieved by the forgiving party. Moreover, in some cases the high level of moral reasoning may be related to the attitude of revenge.

The decision to forgive has been shown to be linked to the relation between the injured party and their offender, particularly in the studies on the process of forgiveness in people harmed by someone important to them, i.e., a family member, a beloved one or a friend. For example, McCullough et al. (1997, pp. 322, 326) have explored the extent to which empathy for the offending partner is the central facilitative condition that leads to forgiving. In their study they assume that in the context of close relationships between the offender and the victim: (1) empathy may cause the offended partner to care that the offending partner is experiencing guilt and distress over his or her actions, (2) empathy may cause the offended partner to care if the offending partner feels isolated or lonely because of their estranged relationship, (3) empathy for the offending relationship partner may simply lead the offended relationship partner to care for restoring the breached relationship with the offending partner (p. 323). A similar study was carried out by Everett Worthington, who constructed an empathy model of forgiveness (1998, p. 107).

Forgiveness may also be conditioned by the injured party's care for their own wellbeing, as indicated mainly by studies on psychological counselling in which forgiveness is presented as a means of dealing with shame, guilt, grief and depression (Thorsen et al. 1998; West 2001, p. 421). This seems to be confirmed also by studies, for example, on health and well-being which show that people may grant forgiveness for the sake of their own interest (Reed and Enright 2006). This is the correct direction of reasoning and action, 
as evidenced by numerous studies on the effects of forgiveness (e.g., West 2001; Rye and Pargament 2002; Harris et al. 2006).

However, forgiving for the sake of one's own well-being may not always be prudent. As mentioned, Worthington's studies (1998, pp. 113-116) also show that people may decide to forgive because, for instance, they are afraid of their offender who is their family member and thus cannot be avoided. In such situations, forgiveness is an attempt to restore the status quo of the relationship, albeit an imprudent one, as forgiveness does not guarantee that the offender will stop to abuse the victim.

In conclusion, it can be said that the decision to forgive is the act through which the injured party strives to overcome the evil caused by the action of another person. As an act of decision-making, forgiveness is primarily dependent on mental powers-reason and will. It is conditioned by the development of reason because it is only through such a development that the individual can see forgiveness as a means of overcoming the negative feelings after being wronged. At the same time, for the path of forgiveness to be chosen it is necessary to desire a good which can be achieved through the decision to forgive; the good expressed, for example, in rebuilding a relationship with the wrongdoer. A very good comment on this may be found in the writings of Hannah Arendt who appreciates the value of forgiveness by saying: "Forgiving serves to undo the deeds of the past, whose 'sins' hang like Democles' sword over every new generation" (Arendt 1958, p. 237). Thomistic philosophy applied to the analysis of forgiveness also allows us to take a closer look at the concept of readiness to forgive, an attitude discussed in greater detail below.

\section{Forgiveness as a moral virtue}

Thomistic philosophy does not only shed some light on the essence of forgiveness, but it also allows one to interpret what conditions one's readiness to forgive. The fundaments for that may be derived from the Thomistic theory of virtue. Before presenting it, I would like once again to refer to the discussion on the essence of morality. The debate on morality seems to lead to a false oversimplification.

Habituated virtues are here contrasted with moral reasoning, as if virtues had nothing to do with deliberate reflection, thus enabling the theory of virtues to be juxtaposed with behaviourist claims. Research into moral education even goes as far as to argue that the pedagogy of forgiveness education programmes breaks the dichotomy according to which the pivotal role in moral development may be attributed either to habit or to reflection: "The forgiveness programme described above emphasises the habituation of virtues such as kindness and, at the same time, teaches students to think critically about behaviour relative to what is fair or just" (Lin et al. 2011, p. 245).

Such statements are only valid for a specific theory of virtue, e.g., when virtue is identified with positive qualities. For instance, if we perceive love as a virtue and forgiveness as an expression of love, then the attitude of forgiveness will be regarded as a virtue, regardless of whether it results in positive or negative consequences. From the point of view of Thomism, this would be taken as a mistake.

Thomistic philosophy offers a completely different theory of virtue under which it would be a great oversimplification to bring it all down to positive qualities. Let us try to briefly review this theory. Firstly, it is a theory which, as a virtue, recognises a quality which makes it easy for the human being to identify what is morally good and act towards it. However, moral good is not determined by an abstract value, but by the effects of the 
undertaken action, visible both in the subject who acts and in the object to whom the action is addressed. Thus, virtue cannot be a mindless, mechanical reaction to certain situations, but an efficient search for good in the given conditions and consistency in acting towards its achievement. This means that under different circumstances virtue might lead to different solutions (Woroniecki 1961).

Secondly, in the Thomistic theory, the respective virtues are subordinated to four cardinal virtues, i.e., prudence, justice, temperance and fortitude (Pieper 1966; Horowski 2015). Prudence is the excellence of reason based on the ability to find the morally best solution in a given situation. Justice is the excellence of will which dictates to choose the solution indicated by reason, i.e., the solution taking into account the good of all the persons involved. Temperance denotes readiness to give up sensuous goods, i.e., those which bring pleasure, if it is necessary to ensure further pursuit of the good indicated by reason. It is worth noting that temperance cannot be simply understood as the equivalent of abandoning sensuous goods, either in part or in their entirety.

Temperance means resignation, but only when it is required for a greater good. When no such need arises, resignation is not necessary and temperance is about enjoying said pleasures; for example, an attractive and expensive trip. If reason points to other needs which the available funds should be used for (e.g., a therapy of the beloved one), then holding back from a trip will be an exemplification of temperance, while going on the trip will denote a lack of such. However, if at the given time no greater needs present themselves, spending the money on an expensive trip does not defy the virtue of temperance.

Similarly, the fourth of the cardinal virtues, the virtue of fortitude, is recognised as a virtue only when it refers to prudent decisions. If reason points to a valuable good that is worth risking the loss of all personal goods, including even health or life, then taking up the challenge to fight for this good, with all the risks and dangers involved, will signify the virtue of fortitude. However, fortitude cannot be non-deliberate or irrational, while risking the loss of some goods for the good that is not worth it cannot be considered an act of fortitude. Such an approach to fortitude leads to the conclusion that while a soldier fighting for his country will commit an act of the virtue of fortitude because the end justifies it and is worth it, but it would be difficult to acknowledge as the virtue of fortitude an attempted ascent of a summit in the Himalayas, even in winter when posing an immediate threat to health or life. In the latter case, it is difficult to compare the end which is to be achieved with the losses that may be sustained not only by the climbers themselves, but also by their relatives, particularly their spouses and children.

According to the Thomistic theory, the character formed by moral virtues is not reflected in a thoughtless, schematic reaction to specific situations, but is manifested through a deliberate action. Virtues are not habits. Virtues are what provides for harmony between human appetitive powers, i.e., will and senses, and reason. The term used here, 'harmony', is in itself very significant. For Thomism, virtue is not about subordinating the senses to reason, but about the harmony of the senses with reason. The former appears when the individual subdues their sensuous reactions by the power of their will. Conversely, harmony is attained when emotions correspond to what is indicated by reason (Maritain 1950, 1968). While this is not the topic of this article, it is worth bearing in mind that in terms of the cardinal virtues character development first requires for the acquisition of subjectivity in the modern sense of the word, whereby the subsequent instructions regarding the morality of actions are treated only as secondary (Horowski 2009).

This brief discussion of the Thomistic theory of moral virtues may now serve as a basis for an attempt to look at forgiveness as a moral virtue. In the light of this theory, the attitude of readiness to forgive is a virtue if it complies with the criteria of the four cardinal 
virtues; it should therefore manifest prudence. Forgiveness exhibits prudence when, in a given situation, it is indicated by reason as a way of achieving good, for example when the wrongdoer seeks to make reparations for the harm they have done (Bassett et al. 2006). Otherwise, if it leads the wrongdoer to believe that they have the right to harm others, forgiveness is not an act of prudence (Richards 1988, p. 82). Similarly, when the injured party takes the decision to forgive in an immature manner because, for instance, they feel pressured by their environment or religion, without giving sufficient care to their own good as it may result in a build-up of negative emotions in them and the feeling of weakness (Richards 1988, p. 78; see West 2001, p. 421). However, if the injured party decides to forgive because they hope that this will change the wrongdoer's way of thinking, then it will fulfil the criterion of prudence.

Connecting forgiveness with justice may raise doubts, as forgiveness is perceived as an act equivalent to resignation from justice (Murphy 1998, pp. 699-700). Upon being forgiven, the wrongdoer receives the right to something that they do not deserve because of the evil they have caused. However, deeper analysis allows this doubt to be dispelled. Firstly, despite the harm they have done, the injuring party has not ceased to be human and thus retains the right to develop, including that to change their attitude. Secondly, justice is also about the enforcement of the rights of the victims which can be exercised only through forgiveness. To illustrate this, I would like to refer to the parable of the prodigal son, wellknown in Western culture (Lk 15: 11-32). A young man who has left his father's house and wasted all his fortune loses the right to stay in his father's house. However, the father has not lost his right to stay with the son he loves. The act of forgiveness allows the father to exercise his rights and, as such, is an act of justice.

The other cardinal virtues, temperance and fortitude, apply directly to feelings. As discussed in the first part of the article, forgiveness is defined in terms of feelings. However, linking it to the virtues of temperance and fortitude, reveals its specific aspects. Firstly, forgiveness means resignation from certain goods to which the individual has the right in the name of a greater good that can be attained through forgiveness. Secondly, it requires addressing the obstacles and difficulties faced on the path towards good. In a way, these may include weaknesses of human nature which lie at the source of moral evil.

However, feelings emerging in the face of evil are a much more complex topic which would require a separate analysis. Here I would only like to point out that next to resentment, anger or contempt, the injured party may fear their offender; a fear which may be particularly strong when the offender is their loved one or a member of family whom they see every day. In such a situation, opting for forgiveness and consequently refraining from the exercise of their own rights may be motivated by their desire to reduce that fear. In such context, it will be indeed an act of fortitude not to forgive, at least until the offender changes their attitude, i.e., the risk of them re-offending disappears, together with the fear felt by the victim.

As the analysis shows, in the Thomistic theory moral virtues cannot be reduced to qualities which once bestowed within an individual will manifest themselves in practice through pre-modelled actions. The achievement of moral virtues is not equivalent to achieving excellence or perfection consistent with a certain ideal. Therefore, their pursuit is not a form of perfectionism. Prudence, justice, temperance and fortitude are present in actions when every situation is approached individually and rationally in search of the best solutions which are then consistently implemented. As such they cannot be applied to behaviourism, which instead offers a concept of schematic habits, implemented automatically without pondering on the situation. Consequently, forgiveness can be regarded as 
a manifestation of moral virtue when it comes from reflection upon a good that may be achieved and subsequent pursuit of that good driven by appetitive powers.

\section{Conclusions}

The analysis leads to conclusions significant for educational work. They may be categorised following the key already applied throughout the article, i.e., they may be divided into actions related to intellect and will. Before moving on to their brief description, I would like to point out that education for forgiveness should never be understood as instruction towards or practising of the skill of forgiveness. This act will always be an individual and difficult decision which requires time and internal struggle. The role of the education for forgiveness is therefore to create conditions which, in a given situation, can facilitate a personal decision, particularly a prudent one. Let us first see how the subject can be prepared for such decision in terms of intellect.

5.1 The discussion of Joseph Butler's sermons shows that it is important to distinguish the feelings of resentment, grief and anger that appear in the injured party from the attitudes that they represent towards the injuring party. As Richards argues, some types of grief are not in contradiction to the positive attitude to the wrongdoer (Richards 1988, p. 83). Part of such an education would therefore be to teach how to make a distinction between these two responses - the spontaneous and emotional one from the well-thought-out, deliberate, rational one. In addition, it would be important to emphasise the positive role of spontaneous feelings experienced by the injured party which in fact protect them from further injury.

5.2 The analysis prompts an indirect conclusion that forgiveness can be facilitated by understanding humanity as such and understanding the specificity of interpersonal relations. What does it mean? There are a few aspects of it, the discussion of which goes beyond the framework of such a short article. However, two areas should be pointed out. Firstly, human accidentality or imperfection. The human is not only a rational being, but also a corporeal one susceptible to emotions. Consequently, living in a community will not only evoke good in people, but also weaknesses which, in many cases, will result in someone being wronged. The second area refers to justice where people who have been harmed are filled with grief and seek revenge. They often fail to notice that they take away from other people their right to the goods which they are entitled to. Resentment towards a husband who has failed or cheated his wife often turns into actions which violate the children's rights to contact with their father.

5.3 Understanding humanity as such can facilitate the understanding of the individual wrongdoer. It may help explore their motives and weaknesses, while sometimes even discovering a person who cannot cope with themselves. In specific situations, such understanding can make it easier to deal with one's own pain and to forgive the offender.

5.4 The analysis also revealed a connection between a valuable forgiveness and positive effects, both in the subject and in terms of human relations. Education can prepare the right ground for forgiveness if it helps people see the whole wide spectrum of consequences of forgiving and non-forgiving. It can also be effective if it teaches learners to determine these consequences not only in relation to the victim and the 
offender, but also with respect to those indirectly involved in a specific relationship and situation.

5.5 An intellectual view of forgiving and non-forgiving may also prevent a hasty and often imprudent decision to forgive; instead of leading to something good, this increases the risk of being wronged again. In Western culture, forgiveness is perceived as a positive value and thus a determinant of action. Sometimes it even presents itself in the "pressure" to forgive. In this context, an action determined by what is culturally valued may turn out to be non-deliberate, irrational and thus lead to evil. The intellectual view of injury and forgiveness may stop the injured party from rushing to actions which have not been thought through and might therefore create perfect conditions for the injuring party to hurt them again.

5.6 Another conclusion refers to what conditions forgiveness in terms of will. From the point of view of Thomistic philosophy, forgiveness seems to be conditioned by the quality of human relationships. If developed for utilitarian reasons, i.e., when a person enters a relationship only to achieve a certain good for themselves they will not seek forgiveness. If harmed by another person, then they will decide to break the relationship. Conversely, if a relationship is established and reinforced with the other person's good in mind, then the desire to maintain it will motivate forgiveness. In other words, readiness to forgive will be developed through education if it focuses on building a community of people able to take responsibility for each other.

5.7 Education for forgiveness needs also to strengthen one's sense of dignity and promote care for one's own well-being. Here, caring may help see positive aspects of forgiveness with respect to the injured party or, on the other hand, it may serve as a reference point for acts of forgiveness in terms of concern for one's own good. It could thus help avoid acts of forgiveness in which the injured party's own well-being is not guaranteed to a sufficient degree.

5.8 The discussion presented here also calls for the need to work on one's feelings, so that they constitute a tool by means of which reason and will can achieve their ends, rather than relying on some autonomous forces that reason cannot control.

These claims result from the understanding of forgiveness and willingness to forgive considered in terms of Thomistic philosophy. Their inclusion in the process of education can help a person faced with such dilemma take the decision to forgive, thereby supporting them in taking a prudent decision. Nevertheless, they should not be understood mechanically as a guarantee of an act of forgiveness, as every act is always conditioned by specific circumstances and individual predispositions.

Open Access This article is distributed under the terms of the Creative Commons Attribution 4.0 International License (http://creativecommons.org/licenses/by/4.0/), which permits unrestricted use, distribution, and reproduction in any medium, provided you give appropriate credit to the original author(s) and the source, provide a link to the Creative Commons license, and indicate if changes were made.

\section{References}

American Psychological Association. (2008). Forgiveness. A sampling of research results. Washington, DC: Office of International Affairs.

Arendt, H. (1958). The human condition. Chicago: The University of Chicago Press.

Bassett, R. L., Bassett, K. M., Lloyd, M. W., \& Johnson, J. L. (2006). Seeking forgiveness: Considering the role of moral emotions. Journal of Psychology and Theology, 34, 111-124. 
Butler, J. (1827). Fifteen Sermons Preached at the Rolls Chapel. Cambridge: Hilliard and Brown. http:// anglicanhistory.org/butler/rolls/index.html.

Garcia, E. V. (2011). Bishop Butler on forgiveness and resentment. Philosophers' Imprint 11, 10, 1-19. http://quod.lib.umich.edu/p/phimp/3521354.0011.010/-bishop-butler-on-forgiveness-andresentment?view=image.

Gilson, E. (1971). Philosophy of St. Thomas Aquinas. (E. Bullough, Trans.). Freeport, NY: Books for Libraries Press.

Griswold, C. L. (2014). Forgiveness. A philosophical exploration. New York: Cambridge University Press.

Hall, J., \& Fincham, F. (2006). Relationship dissolution following infidelity: The roles of attributions and forgiveness. Journal of Social and Clinical Psychology, 25(5), 508-522.

Harris, A. H. S., Luskin, F., Norman, S. B., Standard, S., Bruning, J., Evans, S., et al. (2006). Effects of a group forgiveness intervention on forgiveness, perceived stress, and trait-anger. Journal of Clinical Psychology, 6, 715-733. https://doi.org/10.1002/jclp.20264.

Horowski, J. (2009). Podmiotowość w pedagogice chrześcijańskiej o inspiracji tomistycznej [Being a subject in the light of the Christian educational theory based on Thomistic philosophy]. Paedagogia Christiana, 24, 63-78. https://doi.org/10.12775/PCh.2009.029.

Horowski, J. (2015). Moral education according to neo-thomistic pedagogy. Toruń: Wydawnictwo Naukowe Uniwersytetu Mikołaja Kopernika.

Klatt, J., \& Enright, R. (2009). Forgiveness and positive youth development. Journal of Moral Education, 38(1), 35-52. https://doi.org/10.1037/0003-066X.34.10.932.

Lin, W. N., Enright, R., \& Klatt, J. (2011). Forgiveness as character education for children and adolescents. Journal of Moral Education, 40(2), 237-253. https://doi.org/10.1080/03057240.2011.568106.

Maritain, J. (1950). Three reformers: Luther, Descartes, Rousseau. Westport, CT: Greenwood Press.

Maritain, J. (1968). Integral humanism: Temporal and spiritual problems of a new christendom (J. W. Evans, Trans.). New York: Scribner.

Maritain, J. (1990). An introduction to the basic problems of moral philosophy. New York: Magi.

McCullough, M. E., Worthington, E. L., Jr., \& Rachal, K. C. (1997). Interpersonal forgiving in close relationships. Journal of Personality and Social Psychology, 73(2), 321-336.

Mróz, M. (2001). Man in the dynamism of virtue. Topicality of St. Thomas Aquinas aretology in the light of the question about the fundamentals of christian morality. Toruń: Wyższe Seminarium Duchowne.

Murphy, J. (1982). Forgiveness and resentment. Midwest Studies in Philosophy, 7, 503-516. https://doi.org/ 10.1111/j.1475-4975.1982.tb00106.x.

Murphy, J. (1998). Forgiveness and mercy. In E. Craig (Ed.), Routledge encyclopedia of philosophy (Vol. 3, pp. 697-701). London and New York: Routledge.

Murphy, J. (2003). Getting even. Oxford: Oxford University Press.

Newberry, P. A. (2001). Joseph Butler on forgiveness: A presupposed theory of emotion. Journal of the History of Ideas, 62, 233-244. https://doi.org/10.1353/jhi.2001.0016.

Pieper, J. (1966). The Four Cardinal Virtues: Prudence, Justice, Fortitude, Temperance (R. Winston, C. Winston, L. E. Lynch, D. F. Coogan, Trans.). Chicago: University of Notre Dame Press.

Reed, G., \& Enright, R. D. (2006). The effects of forgiveness therapy on depression, anxiety, and posttraumatic stress for women after spousal emotional abuse. Journal of Consulting and Clinical Psychology, 74, 920-929.

Richards, N. (1988). Forgiveness. Ethics, 99, 77-97.

Rye, M. S., \& Pargament, K. I. (2002). Forgiveness and romantic relationship in college. Can it heal the wounded heart? Journal of Clinical Psychology, 4, 419-441. https://doi.org/10.1002/jclp.1153.

Szulakiewicz, M. (2016). Phenomenology of forgiveness: Moral and metaphysical dimension of forgiveness. Paedagogia Christiana, 37, 97-120. https://doi.org/10.12775/PCh.2016.006.

Thomas Aquinas. (1947). Summa Theologica. http://www.summatheologica.info/.

Thoresen, C. E., Luskin, F., \& Harris, A. (1998). Science and forgiveness interventions: Reflections and recommendations. In E. L. Worthington (Ed.), Dimensions of forgiveness: Psychological research and theological perspectives (pp. 163-190). London: Templeton Foundation.

West, W. (2001). Issues relating to the use of forgiveness in counselling and psychotherapy. British Journal of Guidance and Counselling, 4, 415-423. https://doi.org/10.1080/03069880120085000.

Woroniecki, J. (1961). Nawyk czy sprawność. In J. Woroniecki (Ed.), Wychowanie człowieka. Pisma wybrane (pp. 33-58). Kraków: Znak.

Worthington, E. L. (1998). The pyramid model of forgiveness: Some interdisciplinary speculations about unforgiveness and the promotion of forgiveness. In E. L. Worthington (Ed.), Dimensions offorgiveness: Psychological research and theological perspectives (pp. 107-138). London: Templeton Foundation.

Zarzycka, B. (2016). Psychological concepts of forgiveness in interpersonal relations. Paedagogia Christiana, 37, 163-181. https://doi.org/10.12775/PCh.2016.009. 